\title{
An Empirical Study on Effect of Digitalisation on Homepreneurs
}

\author{
Lucina Priyadarshini Rout ${ }^{1}$, Dr. Snigdharani Panda ${ }^{2}$, Dr. Liji Panda ${ }^{3}$ \\ ${ }^{1}$ Lecturer in Commerce, Niali College, Cuttack, \\ lucina.rout91@gmail.com,9437912682 \\ ${ }^{2}$ Associate Dean, KISS Deemed to be University \\ snigdharani.panda@kiss.ac.in,9776246270 \\ ${ }^{3}$ Lecturer in Commerce, KISS Deemed to be University \\ liji.panda@gmail.com,9861253708 \\ Corresponding author: snigdharani.panda@kiss.ac.in
}

\begin{abstract}
Homepreneurs are independent and empowered by different tools, techniques and online platforms. In this paper researcherstry to study about the concept of Homepreneur and analyse the effect of digital transformation on them. As we know Indian Government continuously motivates people to start their ventures and create employment opportunities. Therefore, many interested candidates have started their business from home. Digital platforms help them for marketing, financial activity, Customer relationship. Digitalisation undoubtedly added colour for the growth and prosperity of Homepreneurs. Besides that it helps to small business sectors for uninterrupted sale of products and service to the ultimate customers through the help of digital platform. To show the effect of digitalisation on Homepreneurs an empirical study was conducted. Primary data are collected from 150 respondents of four districts of Odisha. Statistical tools like paired $t$-test, Regression analysis are effectively uses to assess the information trend and analyse the effect of digitalisation on Homepreneurs. This research try to provides an insight into the real effect of digitalisation on Homepreneurs at grass root level.
\end{abstract}

Keywords: Homepreneur, Digitalisation, Operating cost, Efficiency, Prosperity

\section{INTRODUCTION}

"Homepreneurs"are basically freelancers those who have come at the need of the hour. Homepreneurs are those Entrepreneurs who work from home and are those who have started their business in their own home instead of creating Business House, Office etc. Entrepreneurship is the key to the very growth and Prosperity of a nation. From the beginning of our independence Government of India has been focusing on Pampering Business. But owing to various factors people are still afraid of choosing their career of Entrepreneurship. Lack of Entrepreneurial motive as it is evident, is the main obstacle. Recently the Government of India have undertaken an all out drive to motivate the Citizen for Entrepreneurship. The India Government failed to recognise the problems and facts which were demotivating for people to undertake Ventures. Though late, the present Government have initiated innovative programme like Start Up India, Make In India,
Mudra Bank, Digital India etc. Family, Lack of Skilled Labour, Poor Location etc. are the major stumbling blocks demotivate people for business. This is a "Blessing in Disguise" that the above problems have been timely and appropriately addressed by the Central Government that creates ample opportunities for the "Homepreneurs". Homepreneur now can start their business with very little resources. In Indian perspective Home Based Business is rarely taken as a career opportunity. Homepreneurs therefore are in a experimental, rather a transitional phase. From the last many years due to increase in customer demand, digitalisation, sense of modernisation it has accelerated the trend of driving growth of Home based business to a much higher level. Indian families are rapidly changing due to the increased pace of urbanisation and modernisation. People are now motivated to start their own Business.

Digitalisation is a buzz word for the Business Community today. Digital transformation is the 
process of redefining the entire Business strategy by adopting the latest and emerging digital technology. Digital transformation is the reflective process of transformation of Business as well as Organisational activities, differentbusiness Process, business Competencies etc. In Practical Digital Transformation things are initiated to gain end to end Customer Experience, optimisation of service activities are experience, gaining operational flexibility. As a matter of fact, going digital is the pressing need of the hour, to survive in Business. The main objectives behind digitalisations are to enhance accessibility and improvising Preservation from the previous decades that is clearly witnessed in rapid digitalisation with ever increasing use of smart phones, internet, social media, E-Commerce and on demand service platform becoming a part of our daily life. Many online platforms have also come up enabling Homepreneurs to be online Sellers and Entrepreneurs from their Comfort Zone. Platforms like Mesho, Amazon Shaeli, Shiprocket, Shopmatic, Fintech, ShopClues etc. are flourishing.

Process of Digitalisation has drastically changed the outlook towards Homepreneurs.It has a growing impact on home based business. It helps accelerate a huge shift towards traditional ways of manufacturing, storing, marketing, selling etc. Digital transformation will help the home based Entrepreneurs in various ways like increasing revenue, facilitating access to higher customer base, increasing Operational Efficiency, enhancing Customer Experience and Increasing Digital Outlets.

\section{LITERATURE REVIEW}

The concept of working from home related to business is not new but to get the recognition of "Homepreneur" is too late. In 21stcentury Homepreneurs are supporting manufacturer in selling their products and services. Presently Homepreneurs are coming with new energy, strategy and innovation to compete in the market. Researcher has advocated that there may be a time comes where business man may spent $50 \%$ to $90 \%$ of their time doing work from home (Singh,2012). Digitalisation in India rapidly increasing because in present age customers are preferring digital platform to purchase and sale instead going to physical outlet. Therefore, digitalisation of business is now necessary to sustain in the market (Singh, 2017). Gowsami and Upadhaya (2019) also advocated about the need of digital transformation for improving business operational efficiency and to meet demand of customer. Due to less scope for digital transformation MSMEs in India rescued from thousands of opportunities. Government need to provide all possible and favourable ecosystem to boost MSMEs in digital platform that will surely help to increase working performance of MSMEs (Mishra,2019). Sustainable Development Goals encourages steady economic growth. It helps to create opportunities for entrepreneurship, innovation, technological development and creation of job. Homepreneurs should aware about this so that they can able learn different skill andimprove awareness related to market. Moreover, Social media Giving a wide platform to increase their sale and customer base. As individual level it will help to empower individuals which leads economic growth and sustainable development of the Country (Swami and Naidu,2020, Samanta, 2018). Recent digital revolution encourage women in India to start home based business. Different digital platforms now a days pamper women to go for home based business by balancing work with family (Sachdev and Nair, 2020, Samanta, 2019). The findings of the study shows need of digitalisation for the micro industries of India and it also demonstrate that Digitalisation is the need of the hour for Homepreneurs. The Homepreneurs of India increasing now a days due to effect digital platform. But there are less research and articles on Homepreneurs. So more studies are needed for encouraging Homepreneurs in India.

\section{STATEMENT OF THE PROBLEM}

Recent days Home Based Businesses are in trend. These Entrepreneurship play an important role in the socioeconomic development of a country. Various factors influence the home based Business though digitalisation is indeed the prime mover in the contemporary landscape that precisely carves out a very strong base for promotion of Homepreneurs. Most of the research literature are primarily focused on merits and demerits of Digital Transformation or Impact of Digital Transformation not only Big Business Houses or, motivational factors for Homepreneurs. But at ground level Digital Transformation not only help Big Business house for growth but also makes a change in home based business. Thus the present study is an attempt to represent the effect of Digitalisation on Homepreneurs.

\section{RESEARCH OBJECTIVES}

1) To analyse the impact of different aspects of Digitalisation on business prosperity of Homepreneurs. 
2) To examine the effects of using digital technology on Homepreneurs.

\section{RESEARCH HYPOTHESIS}

1) Different aspects of Digitalisation( Digital Efficiency, Operational Cost, Digital Revenue, Instant Communication, Digital Labour Force, Transparency, Digital Labour force, Digital threats) do not have any real impact on Business Prosperity of Homepreneurs.

2) There is no change in the status of Homepreneurs after using Digital Technology in theirBusiness.

\section{DATA COLLECTION AND SAMPLE SIZE}

This study based on both primary and secondary data. The primary data is collected through a model questionnaire. Questionnaires are responded by Homepreneurs inonline and in person as well. Though it addressed around 200 respondent only 150 respondents gave their views to this survey. From a five pointLikerts type Scale use according to our convince $(1=$ Strongly Disagree, $2=$ Disagree, $3=$ Neither Disagree Nor Agree,4=Agree,5=Strongly Agree).Secondary data collected from various websites, Books, Annual Reports, Journals.

\section{DATA ANALYSIS}

Collected data were analysed with the help of software package SPSS19. Statistical techniques like descriptive analysis, reliability analysis, Multiple Regression Analysis,Paired T-Test were used to analyse the data. From the sample data of 150 respondent 85 respondents are in the age group of 15 to 30,40 respondent are from 30 to 45 age group, 25 respondent are from more than 45 age group. The respondents are from Four Districts of Odisha Khurda, Cuttack, Koraput, Mayurbhanj. Whereas 50 respondents are male and 100 respondents are female. All these Entrepreneurs are from unorganised sector as they donot have any registration. It reflects from the data set more Homepreneurs are female. The above Homepreneurs deal with the businesses like candle making, pickles, agarbatti, art and crafts, handmade biscuit and chocolates, papad, jute and paper bag, toys, organic and beauty products, beauty parlour, Stitching, Garments, Painting, Typing, Face Mask, etc.

\section{Result and Discussion:}

Table-1: Test of Reliability

\begin{tabular}{|l|l|l|}
\hline \multicolumn{2}{|l|}{ Reliability Statistics } \\
\hline $\begin{array}{l}\text { Cronbach's } \\
\text { Alpha }\end{array}$ & $\begin{array}{l}\text { Cronbach's } \\
\text { Alpha Based on } \\
\text { Standardized } \\
\text { Items }\end{array}$ & of Items \\
\hline 0.138 & 0.88 & 9 \\
\hline
\end{tabular}

The above test cronbach's alpha shows .880 which represents good value of reliability on our data set.

The following Curve showed that data are normally distributed

Histogram

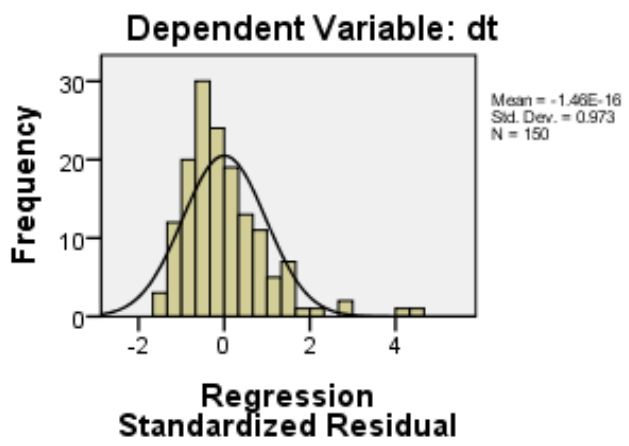

Figure No.1 : Test of Normality

Table No. 2 Correlation of Coefficient

\begin{tabular}{|l|l|l|l|l|}
\hline Model & $\mathrm{R}$ & $\begin{array}{l}\mathrm{R} \\
\text { Square }\end{array}$ & $\begin{array}{l}\text { Adjusted } \\
\text { R Square }\end{array}$ & $\begin{array}{l}\text { Standard } \\
\text { error of } \\
\text { the } \\
\text { estimate }\end{array}$ \\
\hline $\mathbf{1}$ & $.895^{\mathrm{a}}$ & .801 & .790 & .58070 \\
\hline
\end{tabular}

Model Reveals That $\mathrm{R}$ value is 0.895 , it means the correlation coefficient between the dependent and independent variables are strongly positive and $\mathrm{R}$ Square value is .801 which represents the variation between dependent and independent variable is 80.01 percent. It overall represents the model is useful for the data set.

Table No. 3: ANOVA

\begin{tabular}{|l|l|l|l|l|l|l|}
\hline \multicolumn{7}{|l|}{ ANOVA $^{\mathrm{a}}$} \\
\hline \multicolumn{2}{|l|}{ Model } & Sum of squares & df & Mean Square & F & Sig. \\
\hline 1 & Regression & 190.393 & 7 & 27.199 & 79.613 & $.000^{\mathrm{b}}$ \\
\hline
\end{tabular}




\begin{tabular}{|l|l|l|l|l|l|l|}
\hline & Residual & 48.513 & 142 & .342 & & \\
\cline { 2 - 7 } & Total & 238.906 & 149 & & & \\
\hline
\end{tabular}

a. Dependent Variable: Business Prosperity

b. Predictors: (Constant), Digital threats, Operational Cost, Increase Revenue, Digital Efficiency, Instant Communication, Transparency, Digital Labour Force

Significant at $\mathrm{P}<0.05$

\section{Table No. 4: Coefficients}

Coefficients $^{\mathbf{a}}$

\begin{tabular}{|c|c|c|c|c|c|c|}
\hline \multicolumn{2}{|c|}{ Model } & \multicolumn{2}{|c|}{ Unstandardized Coefficients } & \multicolumn{3}{|c|}{ Standardized Coefficients } \\
\hline & & B & Std. Error & Beta & $\mathrm{T}$ & Sig. \\
\hline \multirow[t]{8}{*}{1} & (Constant) & -.294 & .170 & & -1.737 & .085 \\
\hline & Digital Efficiency & .177 & .072 & .155 & 2.455 & .015 \\
\hline & Operational Cost & .002 & .019 & .005 & .112 & .911 \\
\hline & Increase Revenue & .112 & .056 & .107 & 2.006 & .047 \\
\hline & Instant Communication & .422 & .080 & .374 & 5.297 & .000 \\
\hline & Digital Labour Force & .163 & .077 & .154 & 2.111 & .036 \\
\hline & Transparency & .201 & .071 & .179 & 2.832 & .005 \\
\hline & Digital threats & .066 & .061 & .063 & 1.087 & .279 \\
\hline
\end{tabular}

a. Dependent Variable: Business Prosperity

***Denotes significant level at 5\%

The regression equation is

$\mathrm{Y}=--.294+.177 \mathrm{X} 1+-$

$.002 \times 2+.112 \times 3+.422 \times 4+.163 \times 5+.201 \times 6+.066 \times 7$

The above table shows the true result of our survey. According to the above study it represents that impact of digital factors like Digital Efficiency, Operational Cost, Digital Revenue, Instant Communication, Digital Labour force, Digital Threats has significant and non significant impact on the constant Business Prosperity.

X1(Digital Efficiency): it has a significant impact $(.015)$ on the constant, which is positively correlated(2.455) with the constant.

X2(Operational Cost): According to the survey operational cost does not have any significant (.911) impact on constant, here null hypothesis is accepted.

X3(Digital Revenue): It also represents a significant impact (.047) on constant, Due to more use of Digital gateway ultimately it helps increase sale as a result revenue also increases. Here Null Hypothesis is Rejected

X4(Instant Communication): It states that due to digitalisation, Homepreneurs can able to make instant communication through different digital platforms, it has a significant impact on business prosperity.

X5(Digital Labour Force): To find out skilled labour force is difficult task for home based Business, Due to digitalisation entrepreneur can contact skilled labour in different corner of the country and work according to their customer demand. In this survey it shows a significant positive impact.

X6(Transparency): It reflects significant positive impact on Homepreneurs. All the financial statements, products details can share one to one customer.

X7(Digital Threats): For the present study we can concluded that respondents do not feel any digital threats still now, it means digital threats does not have any significant impact on Business growth.

From the above data operational cost and Digital threats does not have any significant impact on business prosperity of Homepreneurs. Accept the null hypothesis, where as other factor put strong impact with positive correlation on business prosperity of Homepreneurs. Due to shortage of time and mobility only seven aspects of digitalisation taken into consideration for the present study. But here still Business Prosperity shows negative impact due to effect of COVID-19 purchasing power of digital customer decreases, as well as recession, and less digital knowledge business prosperity shows negative impact.

\section{CHANGE IN STATUS OF HOMEPRENEURS}

Ten parameters are taken to analyse the change in status of Homepreneurs these are as follows Income, Business Growth, Efficiency, Technological Up gradation, Customer Base, Social Status, Standard of Living, Motivation, Public Relation, Demand. 
Table No.5 : Paired t-test

Paired sample Test

\begin{tabular}{|l|l|l|l|l|l|}
\hline \multicolumn{6}{|c|}{ Paired Sample Statistics } \\
\hline \multicolumn{2}{|c|}{} & Mean & $\mathrm{N}$ & Std. Deviation & Std Error Mean \\
\hline Pair 1 & Before & 1.20 & 10 & .422 & .133 \\
\cline { 2 - 6 } & After & 2.10 & 10 & .876 & .277 \\
\hline
\end{tabular}

\begin{tabular}{|c|c|c|c|c|c|c|c|c|c|}
\hline & & \multicolumn{5}{|c|}{ Paired Differences } & \multirow[t]{3}{*}{$\mathrm{t}$} & \multirow[t]{3}{*}{$\mathrm{df}$} & \multirow{3}{*}{$\begin{array}{l}\text { Sig. }(2- \\
\text { tailed) }\end{array}$} \\
\hline & & \multirow[t]{2}{*}{ Mean } & \multirow[t]{2}{*}{$\begin{array}{l}\text { Std. } \\
\text { Deviation }\end{array}$} & \multirow{2}{*}{$\begin{array}{l}\text { Std. } \\
\text { error } \\
\text { mean }\end{array}$} & \multicolumn{2}{|c|}{$\begin{array}{l}95 \% \text { confidence interval } \\
\text { of the difference }\end{array}$} & & & \\
\hline & & & & & Lower & Upper & & & \\
\hline $\begin{array}{l}\text { Pair } \\
1\end{array}$ & $\begin{array}{l}\text { Before } \\
\text { - After }\end{array}$ & -.900 & .738 & .233 & -1.428 & -.372 & -3.857 & 9 & .004 \\
\hline
\end{tabular}

*** Significant $\mathrm{P}>.004$

From the above statistical test it represents that after adoption of technological transformation there is significant change of the status of Homepreneurs.

\section{CONCLUSION}

The present research and literature represents the influence of digital transformation on Homepreneurs. It demonstrated the effect of digital activity for Business and personal growth. On the Basis of information available in the study one can generalise that adoption of digital activity in business has given a immense positive result with a prospective of development. Further this research work hasgiven an insight that Digital Transformation provide expose to the Small Business holders like Homepreneurs. From getting Raw Material, Making Financial Transaction to creating Customer Base Digitalisation put its mark. Digital Transformation is the golden gate way for Prosperity and Development of Homepreneurs. A Country like India where unregistered Home based businesses are more than registered Business, Here Digitalisation helps them to develop new outlook towards Business. Now a days Government provide all possible opportunities to empower entrepreneurship so Homepreneurs or those persons have skills should think about business because not only Government but also digitalisation making business activities easy to access. Now a days digital gate way create opportunities to homepreneurs to marketing their products by different social media platforms, Homepreneurs can improve their skills by using different social media interactive network. Homepreneurs are learning creating website, digital money transactions gateway, they can hire experts through social media, they can able to communicate with their customer one to one to know their query and demand, they can able to produce goods and services through modern technology. All total Digitalisation has an great impact on Homepreneurs Development. So Government should provide more digital facilities to small or home based business to accelerate economic Growth of the Country.

\section{SUGGESTIONS}

As we Know Digitalisation of Small Business is the Need of the Hour. The following suggestions we can conclude that from the above study:

a) Government should provide training to home based business persons about the Digital Utilities

b) Different schemes and environment should create by Government for Digitalisation of small business

c) Awareness of digitalisation should explore from different geographical areas of the Country

d) Last but the least one person should have a strong will Power and curiosity about Business and Digital Transformation.

\section{REFERENCES}

[1] Aral, S., Dellarocas, C., and Godes, D. "Introduction to the special issue-social media and business transformation: a framework for research. Information Systems Research", International Small Business Journal,2013, Vol. 24,No.1,(2013), 3-13.

[2] Nadkarni1 and Prügl R. "Digital transformation. "A review, synthesis and opportunities for 
future research", Management Review Quarterly, Vol.3, No 2,(2020), 31-45.

[3] Downes L, Nunes P."Big bang disruption". Harv Bus Rev, Vol.54, No.2, (2013), 44-56.

[4] Naidu D. and Iresh S. "Social Media Marketing. "Gateway to Success for Homepreneurs", Indian Journal review, Vol.9, No.4,(2020), 2778-3075.

[5] Goswami B. and Upadhyay U. "An Empirical Study on Digital transformation and its impact on Employee Engagement", Elsevier, (2019),1022-1033.

[6] S.Samanta, Soft Competency in Corporate Management, Parikalpana: KIIT Journal of Management 15 (1/2) (2019) 293-294.

[7] S. Samanta, Social Entrepreneurship Promoting Inclusivity, Empowerment and Participative Governance-A Bibliographic Insight, The Indian Journal of Commerce 71 (03 \& 04) (2018) 34-48.

[8] Singh P. "Impact of digitalization on small andMedium enterprises in India",Indian Journal of Research,Vol.6,No.4,(2017), 468-469.

[9] https://timesofindia.indiatimes.com/trendtracking/homepreneurs-socialmediaecomm/articleshow/62095397.cms

[10] http://www.entrepreneur.com/article/341608

[11] https://www.morebusiness.com/home-basedentrepreneurs/

[12] Under 30 CEO, retrieved from : https://www.under30ceo.com/10-qualities-of-asuccessful-entrepreneur 